\title{
População e família no Brasil contemporâneo: muitas mudanças e algumas reflexões
}

Os temas referentes à população e à sua estrutura e dinâmica constituem a matéria-prima dos artigos publicados na Rebep. Com os olhos voltados para todas as dimensões temporais (presente, passado e futuro), os demógrafos e especialistas de áreas afins vêm contribuindo para compreender e interpretar as variáveis demográficas e os impactos que suas alterações podem ter em nossa sociedade. Uma apreciação abrangente sobre a população brasileira, abarcando desde os meados do século XX até o final da primeira década do século XXI, revela mudanças profundas. Em 1940, éramos pouco mais de 40 milhões, em 2010 ultrapassamos os 190 milhões. Como estamos? Transformamo-nos numa população mais urbana, que vive mais, que gera menos filhos e que fica cada vez mais velha. De um país eminentemente rural e agrário, passamos a ser um país industrializado e com predomínio da população urbana, com uma taxa de urbanização que chega perto de $85 \%$. Além disso, enquanto naquela época mais da metade da população era analfabeta, hoje o índice de analfabetismo está em torno de $12 \%$.

Vivemos mais, independentemente do sexo. A esperança média de vida mais que duplicou em relação ao início dos anos novecentos. Como consequência, a população brasileira está mais velha. Se, em 1950, para cada 100 pessoas jovens, menos de 6\% tinham mais de 65 anos, em 2009, este grupo já ultrapassava os $32 \%$. Assistimos também ao consistente descenso da natalidade e da mortalidade infantil e, nesse último quesito, o Brasil apresentou queda significativa, em que pesem as grandes variações regionais. A melhoria desses indicadores pode ser atribuída ao desenvolvimento de políticas públicas introduzidas, especialmente, a partir das décadas de 1970 e 1980, que visavam diminuir as profundas diferenças que marcavam a nossa população.

Outro aspecto que merece ser registrado diz respeito às mudanças nas famílias. Basta citar que, desde 2009, a distribuição percentual dos arranjos domiciliares indica que os casais com filhos deixaram de ser maioria: em 1999, segundo o IBGE e a PNAD (Pesquisa Nacional por Amostra de Domicílios), eles conformavam 55\% dos domicílios, passando a representar $47 \%$ do total, em 2009. Além disso, verificou-se o aumento das unidades compostas por casais sem filhos (de 13\% para 17\%, no mesmo período).

Esta é uma tendência interessante. Pelo visto, pode-se deduzir que mais e mais casais estão optando por manter uma relação que exclui a participação de crianças/filhos. São as "famílias de dois", ou os "casais Dinc" (duplo ingresso, nenhuma criança): ambos têm rendimentos e optaram por não ter filhos. Esta é uma mudança sensível para uma sociedade em que, até poucas décadas atrás, as pessoas eram educadas para se casar e procriar, como se o sucesso da família ou mesmo a felicidade delas dependesse disso.

Os novos e variados arranjos familiares permitem uma convivência plural dentro das casas e estão gerando a necessidade de se compreender a "vida em família" sob outros moldes, incluindo as mudanças nos papéis desempenhados por homens e mulheres.

Outra novidade diz respeito à relação entre filhos e pais: nas últimas décadas, tem sido reforçada a tendência de que os filhos permanecem cada vez por mais tempo na casa dos pais. Se, anteriormente (desde os anos 1970 pelo menos), falava-se da "síndrome do ninho vazio" que ocorria com muitos pais (especialmente as mães) no momento em que os filhos crescidos 
saíam da casa, hoje talvez devêssemos falar na "síndrome do ninho permanentemente cheio", já que os filhos em idade adulta não querem ou não conseguem deixar a casa dos pais.

Resta evidente o fato de que as grandes transformações pelas quais a população e a família brasileira têm passado nas últimas décadas constituem temas desafiadores para os estudiosos, não apenas pelas questões que colocam, mas também pela necessidade de desenvolver métodos e técnicas para avaliar e interpretar esses câmbios.

Este número da Rebep apresenta contribuições importantes sobre alguns desses temas e oferece uma oportunidade para avaliar as transformações que estão caracterizando a sociedade brasileira e, mais amplamente, as sociedades contemporâneas.

Assim, os problemas das sociedades e dos ambientes urbanos trazem para a pauta de discussão, além do bônus, o ônus do avanço da urbanização. Artigos reunidos neste número contribuem para este debate, revelando que esse ônus tem facetas variadas.

Nessa linha, o artigo de Marandola Jr. e de Modesto analisa os perigos ambientais urbanos e as vulnerabilidades em regiões metropolitanas paulistas, focando aspectos sobre a renda, a escolaridade e o ciclo vital. Por sua vez, Mollinatti e Peláez, alargando a discussão para o espaço platino, abordam o caso de Córdoba, chamando a atenção para as desigualdades, a pobreza e a exclusão social nos espaços urbanos, a partir do exemplo daquela cidade argentina.

As transformações do estilo de vida das populações que vivem em áreas urbanas têm tido impactos em diferentes aspectos, alguns dos quais tratados em artigos que também integram esse número da Rebep.

Assim, em questões que são desdobramentos das mudanças na sociedade brasileira e que afetam a saúde da população, o trabalho de Costa e Thuler estudou 18 capitais brasileiras, indicando que os fatores associados ao risco para doenças não transmissíveis estão ganhando espaço em relação às doenças infecciosas em adultos brasileiros, por conta do excesso de peso, sedentarismo, entre outras causas. $\mathrm{O}$ artigo de Corso e colaboradores, de alguma maneira, aponta na mesma direção, ao analisar os fatores comportamentais ligados ao sobrepeso e à obesidade em crianças que estão no ensino fundamental no Estado de Santa Catarina. Como se vê, o estilo de vida dos brasileiros nas áreas urbanas está impactando negativamente a saúde de amplas faixas de população.

A contribuição de Assunção e colaboradores analisa as vulnerabilidades ocupacionais, com destaque para a situação dos trabalhadores de saúde que atuam no SUS, revelando agentes estressores e outros fatores de ambiente que atingem negativamente esse grupo de profissionais.

A outra face da medalha, isto é, a mudança em áreas rurais está no estudo do impacto que a reforma da previdência social rural brasileira está causando nos arranjos familiares, que é o tema do artigo de Ramos e Arend. Os autores focam essa temática a partir da observação da composição dos domicílios que tiveram aumento de renda em função dos idosos elegíveis para receberem os benefícios da reforma previdenciária.

Outro conjunto de artigos que integram esse número da Rebep traz contribuições de caráter metodológico variado, que vão desde a discussão do uso da metodologia qualitativa em Demografia, de Rodríguez Gómez, passando pela temática da estimação dos sub-registro de óbitos em pequenas áreas (nível municipal), a partir do uso de metodologias diferenciadas, de Justino e colaboradores, até o trabalho de Soares e colaboradores que tem como tema a aplicação do método de ampliação das redes sociais, utilizada para as populações "difíceis de contar", como os emigrantes em situação irregular.

De olho também nos comportamentos das populações do passado, essa edição da Rebep abre espaço para conhecermos um pouco mais sobre os padrões de nupcialidade na economia cafeeira de São Paulo entre os finais do século XIX e primeiras décadas do XX, por meio do artigo de Oswaldo Truzzi.

Na seção Ponto de Vista, Siân Curtis chama a atenção para a necessidade de estudos sobre a dinâmica de métodos anticoncepcionais no Brasil, diante da transição da fecundidade observada no país. As Notas de Pesquisa que compõem esse número também oferecem opor- 
tunidade para avaliarmos a riqueza e a diversidade das temáticas que os estudos de população podem trazer aos leitores da Rebep, a partir de estudos que têm como tema as Minas Gerais. Nesse sentido, Radicchi analisa um problema recorrente nas sociedades contemporâneas urbanizadas: a poluição na bacia da Região Metropolitana de Belo Horizonte e sua repercussão na saúde pública. Também podemos entrever aspectos da família e da demografia mineira entre os séculos XVIII e XX, apresentados por Botelho. Fechando o volume, temos as resenhas de Simai e Baeninger, de Feitosa e de Tomás.

Boa leitura a todos(as)!

Ana Silvia Volpi Scott 